\title{
PENGARUH MODEL PEMBELAJARAN THINK PAIR AND SHARE DITINJAU DARI KEMANDIRIAN BELAJAR TERHADAP HASIL BELAJAR IPS SISWA
}

\author{
Elan Artono Nurdin' ${ }^{1}$ Bejo Apriyanto ${ }^{1}$, Fahrudi Ahwan Ikhsan ${ }^{1}$, Fahmi Arif Kurnianto ${ }^{1}$ \\ ${ }^{1}$ Program Studi Pendidikan Geografi, Fakultas Keguruan dan Ilmu Pendidikan, Universitas Jember \\ e-mail: elan.fkip@unej.ac.id
}

\begin{abstract}
Abstrak
Penggunaan model pembelajaran think pair and share (TPS) dalam pembelajaran IPS diharapkan bisa melatih siswa dalam kemandirian belajarnya. Kemandirian belajar merupakan aspek kepribadian yang penting bagi individu dalam pembelajaran, karena individu yang mempunyai kemandirian belajar tinggi relatif dapat menghadapi permasalahan secara mandiri tanpa tergantung orang lain. Dengan kemandirian belajar tinggi, siswa akan termotivasi untuk lebih giat dalam pembelajaran yang akan mempengaruhi hasil belajarnya. Penelitian ini merupakan penelitian eksperimen semu (quasi experiment) dengan desain factorial $2 \times 2$. Instrumen penilaian hasil belajar menggunakan tes esai. Hasil penilaian berupa data yang selanjutnya dianalisis menggunakan model ANAVA dua jalur dengan bantuan program SPSS 16.0 for Windows. Tujuan dari penelitian ini adalah untuk mengkaji model Think Pair Share yang dapat menjadi salah satu solusi dalam pembelajaran lebih efektif dan menyenangkan terutama pada pembelajaran IPS.
\end{abstract}

Kata Kunci: model pembelajaran think pair share, kemandirian belajar, hasil belajar

\section{PENDAHULUAN \\ PENDAHULUAN}

Pembelajaran merupakan upaya untuk meningkatkan hasil belajar secara optimal. Pencapaian hasil belajar yang baik harus menumbuhkan interaksi siswa yang tidak dibatasi hanya pada penggunaan buku semata, tetapi dapat berupa pemberian masalah yang dipecahkah secara bersama-sama. Namun, permasalahan yang diberikan hendaknya yang sesuai dengan tingkat berfikir siswa tanpa terpaku dengan permasalahan yang ada di buku paket.

Salah satu materi IPS geografi yang banyak membelajarkan konsep adalah materi pokok tentang peta, atlas, dan globe. Banyaknya konsep pada materi tersebut membuat siswa mengalami kesulitan dalam mempelajari dan memahami materi tersebut apabila siswa diajarkan dengan model yang kurang sesuai dengan karakteristik materinya. Hal ini dapat berpengaruh pada hasil belajar yang rendah.

Realita di sekolah bahwa siswa belum mampu memahami serta mengaitkan materi dengan kehidupan mereka. Guru sudah menggunakan model pembelajaran yang inovatif, namun model tersebut masih kurang sesuai dengan karakteristik materinya, namun hasil belajar yang ingin dicapai kurang maksimal. Oleh karena itu, dalam pembelajaran perlu digunakan suatu model pembelajaran yang sesuai dengan karakteristik materi, terutama yang dapat membantu siswa secara mandiri dalam mengkonstruksi seluruh konsep dengan baik.

Pembelajaran yang ideal adalah pembelajaran yang berorientasi pada siswa (student centered), siswa akan berusaha mengkonstruksi sendiri pengetahuannya dan terlibat aktif dalam mencari informasi. Hal ini selaras dengan pendapat Rusman (2012:193) yakni pandangan konstruktivisme siswa tidak begitu saja menerima pengetahuan dari orang lain, tetapi siswa harus membangun pengetahuannya dan memberi makna melalui pengalaman yang nyata. Oleh karena itu, diperlukan suatu upaya yang berorientasi pada peningkatan aktivitas dan hasil belajar siswa dengan menerapkan model pembelajaran yang efektif. Salah satunya adalah model pembelajaran think pair share. Dengan model pembelajaran 
ini siswa dilatih secara mendiri bagaimana mengutarakan pendapat dan menghargai pendapat siswa lainnya.

TPS (Think-Pair-Share) atau (Berfikir-Berpasangan-Berbagi) merupakan jenis pembelajaran kooperatif yang dirancang untuk mempengaruhi pola interaksi siswa. TPS menghendaki siswa bekerja saling membantu dalam kelompok kecil (2-6 anggota) dan lebih dirincikan oleh penghargaan kooperatif, dari pada penghargaan individual (Ibrahim dkk: 2000: 3) . TPS digunakan untuk menciptakan interaksi yang dapat mendorong rasa ingin tahu, ingin mencoba, bersikap mandiri, dan ingin maju. Guru memberi informasi, hanya informasi yang mendasar saja, sebagai dasar pijakan bagi anak didik dalam mencari dan menemukan sendiri informasi lainnya. Atau guru menjelaskan materi dengan mengaitkannya dengan pengalaman dan pengetahuan anak sehingga memudahkan mereka menanggapi dan memahami pengalaman yang baru bahkan membuat anak didik mudah memusatkan perhatian. Karenanya guru sangat perlu memperhatikan pengalaman dan pengetahuan anak didik yang didapatinya dalam kehidupan sehari-hari.

Think-pair-share adalah strategi kerja kelompok yang meminta siswa individual di dalam pasangan belajar untuk pertama-tama menjawab pertanyaan dari guru dan kemudian berbagi jawaban itu dengan seorang rekan (Kagan dalam Eggen dan Kauchak, 2012:134). Berdasarkan pendapat tersebut bahwa penggunaan model pembelajaran tipe think-pair-share dapat mengembangkan kemampuan mengungkapkan ide atau gagasan secara mandiri dan membandingkannya dengan ide-ide orang lain.

Selain itu, titik pusat (fokus) dapat tercipta melalui upaya merumuskan masalah yang hendak dipecahkan, merumuskan pertanyaan yang hendak dijawab, atau merumuskan konsep yang hendak ditemukan. Dalam upaya itu, guru menggunakan strategi pembelajaran kooperatif tipe TPS. Strategi TPS dimaksudkan sebagai alternatif terhadap struktur kelas tradisional seperti resitasi, dimana guru mengajukan pertanyaan kepada seluruh siswa dan siswa memberikan jawaban setelah mengangkat tangan dan ditunjuk. Strategi ini menantang asumsi bahwa seluruh resitasi dan diskusi perlu dilakukan di dalam lingkungan seluruh kelompok.

Penggunaan model pembelajaran Think-Pair-Share diharapkan siswa dapat mengembangkan keterampilan berfikir dan menjawab dalam komunikasi antara satu dengan yang lain, serta bekerja saling membantu dalam kelompok kecil. Hal ini sejalan dengan pendapat Arends dalam Komalasari (2011:64) yang menyatakan bahwa ciri khas model pembelajaran kooperatif think-pair-share yaitu suatu model pembelajaran kooperatif yang memberi siswa lebih banyak waktu untuk berpikir, untuk merespon dan saling membantu.

Dengan demikian jelas bahwa melalui model pembelajaran Think-Pair-Share, siswa secara langsung dapat memecahkan masalah, memahami suatu materi secara berkelompok dan saling membantu antara satu dengan yang lainnya, membuat kesimpulan (diskusi) serta mempresentasikan di depan kelas sebagai salah satu langkah evaluasi terhadap kegiatan pembelajaran yang telah dilakukan. Model think-pair-share menekankan optimalisasi partisipasi siswa yaitu dengan memberikan kesempatan sedikitnya delapan kali lebih banyak kepada setiap siswa untuk dikenali dan menunjukkan partisipasi mereka kepada orang lain (Lie, 2010:57).

Tahap pertama penggabungan model pembelajaran Think Pair Share merangsang perkembangan kognitif siswa adalah pada tahap Think. Tahap Think memberikan kesempatan kepada siswa berupa waktu untuk berpikir secara individu. Selain itu, pada tahap Think juga membantu siswa waktu untuk memusatkan pemikirannya pada pelajaran karena siswa dituntut untuk menyelesaikan tugas secara individu yang nantinya akan melaporkan hasil pemikirannya kepada siswa yang menjadi pasangannya. Tahap ini dapat melatih siswa untuk membangun pemahamannya sendiri dari pengetahuan awal yang telah diperoleh. Implikasinya adalah siswa akan semakin memahami konsep dan pengetahuan yang ada sesuai dengan tingkatan kognitifnya sehingga hasil belajar kognitif yang 
dicapai oleh siswa semakin maksimal. Pernyataan tersebut sejalan dengan pendapat Gunter (1999) dalam Harjono (2012:28) menyebutkan bahwa think pair share adalah suatu teknik sederhana dengan keuntungan besar. Think pair share dapat meningkatkan kemampuan siswa dalam mengingat suatu informasi.

Tahapan selanjutnya setelah siswa menyelesaikan tugas secara individu pada tahap Think, siswa akan melaporkan hasil pemikirannya pada teman pasangan (Pair) dan kemudian menyampaikannya pada teman sekelas (Share). Serangkaian tahap ini menekankan aspek kerjasama antar siswa, sehingga akan membuat siswa mampu menguasai materi secara lebih baik. Slavin (2005) Tahap utama dalam pembelajaran Think-Pair-Share menurut Ibrahim (2000: 26-27) sebagai berikut:

Tahap 1 : Think (berpikir)

Guru mengajukan pertanyaan atau isu yang berhubungan dengan pelajaran. Kemudian siswa diminta untuk memikirkan pertanyaan atau isu tersebut secara mandiri untuk beberapa saat.

Tahap 2 : Pairing

Guru meminta siswa berpasangan dengan siswa lain untuk mendiskusikan apa yang telah dipikirkannya pada tahap pertama. Dalam tahap ini, setiap anggota pada kelompok membandingkan jawaban atau hasil pemikiran mereka dengan mendefinisikan jawaban yang dianggap paling benar, paling meyakinkan, atau paling unik. Biasanya guru memberi waktu 4-5 menit untuk berpasangan.

Tahap 3 : Share (berbagi)

Pada tahap akhir, guru meminta kepada pasangan untuk berbagi dengan seluruh kelas tentang apa yang telah mereka bicarakan. Keterampilan berbagi dalam seluruh kelas dapat dilakukan dengan menunjuk pasangan yang secara sukarela bersedia melaporkan hasil kerja kelompoknya atau bergiliran pasangan demi pasangan hingga sekitar seperempat pasangan telah mendapat kesempatan untuk melaporkan.

\section{METODE}

Metode yang digunakan pada penelitian ini adalah eksperimen semu (Quasi Eksperimen). Untuk penelitian ini desain yang digunakan adalah factorial design dengan rancangan faktorial $2 \times 2$. Ini memungkinkan penggunaan desain faktorial untuk mengkaji bukan hanya memisahkan pengaruh dari setiap variabel bebas tetapi juga pengaruh dari penggabungannya. Dengan kata lain, peneliti dapat melihat bagaimana salah satu variabel menjadi penengah yang lainnya.

Berdasarkan desain faktorial diatas, sejalan dengan yang dikemukakan oleh Sugiyono (2009: 113) tentang desain faktorial adalah "Merupakan modifikasi dari design true experimental yaitu dengan memperhatikan kemungkinan adanya interaksi dari (variabel moderator) kemandirian belajar yang mempengaruhi (variabel independen) model pembelajaran think pair share terhadap hasil belajar (variabel dependen). Penelitian ini dilakukan untuk mencari pengaruh model pembelajaran think pair share terhadap hasil belajar IPS ditinjau dari kemandirian belajar

Tabel 1. Rancangan Penelitian Eksperimen

\begin{tabular}{|c|c|c|c|}
\hline $\begin{array}{c}\text { Kemandirian Belajar } \\
\text { (B) }\end{array}$ & Think pair share (A1) & $\begin{array}{c}\text { Pembelajaran Reguler } \\
\text { (A2) }\end{array}$ & Jumlah \\
\hline Tinggi (B1) & A1-B1 & A2-B1 & B1 \\
\hline Rendah (B2) & A1-B2 & A2-B2 & B2 \\
\hline jumlah & A1 & A2 & \\
\hline
\end{tabular}

Subjek dalam penelitian adalah seluruh siswa kelas SMP Negeri 2 Jember semester genap 2016/2017 yang terdiri dari dua kelas. Sampel yang digunakan dalam penelitian ini berjumlah dua kelas 
dari empat kelas dengan teknik purposive random sampling. Teknik ini dilakukan dengan mempertimbangkan pada kemampuan siswa yang hampir sama atau setara berdasarkan nilai UTS dan telah dilakukan perhitungan menggunakan Microsoft Excel 2007.

\section{HASIL DAN PEMBAHASAN}

Teknik analisis data pada penelitian ini menggunakan anava dua jalur, teknik analisis data pada penelitian ini meliputi Uji normalitas sampel dimaksudkan untuk menguji normal tidaknya sampel, pengujian diadakan dengan maksud untuk melihat normal tidaknya sebaran data yang akan dianalisis. Untuk menguji normalitas ini digunakan metode Lilliefors. Metode ini digunakan apabila datanya tidak bergolong, dengan prosedur:

Hipotesis

Ho : sampel berasal dari populasi yang berdistribusi normal

H1 : sampel tidak berasal dari populasi yang berdistribusi normal

Sampel berasal dari populasi yang berdistribusi normal jika H0 diterima. Sampel tidak berasal dari populasi yang berdistribusi normal jika H0 ditolak (Budiyono, 2009: 170).

Tabel 2. Uji normalitas

\begin{tabular}{|l|l|r|r|}
\hline \multicolumn{4}{|c|}{ One-Sample Kolmogorov-Smirnov Test } \\
\hline \multicolumn{2}{|c|}{} & $\begin{array}{c}\text { Kemandirian } \\
\text { Belajar }\end{array}$ & \multicolumn{1}{c|}{ Hasil_IPS } \\
\hline $\mathrm{N}$ & Mean & 40 & 40 \\
\hline Normal Parametersa,,b & Std. Deviation & 84.3333 & 75.5910 \\
\hline & Absolute & 9.08160 & 12.30790 \\
\hline $\begin{array}{l}\text { Most Extreme } \\
\text { Differences }\end{array}$ & .090 & .121 \\
\hline & Positive & .090 & .110 \\
\hline & & &. .121 \\
\hline & Negative & -.065 & .736 \\
\hline Kolmogorov-Smirnov Z & & .494 & .245 \\
\hline Asymp. Sig. (2-tailed) & .521 & \\
\hline a. Test distribution is Normal. b. Calculated from data. & & \\
\hline
\end{tabular}

Berdasarkan pengolahan SPSS pada Tabel di atas menunjukkan bahwa kemandirian belajar menunjukkan nilai signifikansi $\mathrm{p}=0,521$ ( $\mathrm{p}>0,05)$, dengan demikian data kemandirian belajar berdistribusi nomal. Data hasil belajar IPS diperoleh nilai signifikasi $\mathrm{p}=0,245$ ( $\mathrm{p}>0,05)$, maka dapat dikatakan bahwa data hasil belajar IPS pada siswa yang diajarkan melalui pembelajaran reguler maupun menggunakan model pembelajaran think pair share berdistribusi normal.

Uji homogenitas ditujukan untuk menentukan t-tes yang akan dipakai dalam uji hipotesis dan untuk mengetahui apakah hasil tes dari kelas eksperimen 1 dan kelas eksperimen 2 dari populasi yang variannya sama atau tidak. Uji varian ini menggunakan rumus korelasi product moment. Hasil uji homogenitas pada penelitian ini dapat dilihat pada tabel berikut:

Tabel 3. Uji homogenitas

\begin{tabular}{|c|c|c|c|}
\hline \multicolumn{4}{|c|}{$\begin{array}{l}\text { Levene's Test of Equality of Error } \\
\text { Variancesa }\end{array}$} \\
\hline \multicolumn{4}{|c|}{ Dependent Variable: hasil Belajar IPS } \\
\hline $\mathrm{F}$ & df1 & $\mathrm{df} 2$ & Sig. \\
\hline 1.469 & 3 & 36 & .160 \\
\hline
\end{tabular}


Berdasarkan tabel tersebut menunjukkan bahwa nilai signifikansi hasil belajar IPS adalah $\mathrm{p}=$ 0,160 ( $p>0,05$ ), maka dapat dikatakan bahwa data hasil belajar IPS pada siswa yang diajarkan melalui pembelajaran reguler maupun menggunakan model pembelajaran think pair share homogen, artinya data variabel hasil belajar IPS berdasarkan kemandirian belajar mempunyai varian yang sama.

Untuk Uji hipotesis pada penelitian ini menggunakan anava dua jalur. Anava digunakan untuk menguji signifikansi perbedaan efek dua faktor A dan B serta interaksi terhadap variabel terikat.

Hipotesis :

$\mathrm{H}_{0 \mathrm{~A}}$ : tidak ada pengaruh penggunaan think pair share terhadap hasil belajar IPS .

$\mathrm{H}_{0 \mathrm{~B}}$ : tidak ada pengaruh hasil belajar IPS dengan kemandirian belajar tinggi dan rendah.

$\mathrm{H}_{0 \mathrm{AlB}}$ : tidak ada pengaruh penggunaan think pair share dengan kemandirian belajar tinggi dan rendah terhadap hasil belajar IPS.

$\mathrm{H}_{0 \mathrm{~A} 2 \mathrm{~B}}$ : tidak ada pengaruh pembelajaran reguler dengan kemandirian belajar tinggi dan rendah terhadap hasil belajar IPS.

Komputasi :

A : penggunaan model pembelajaran think pair share pada pembelajaran IPS

B : kemandirian belajar siswa

A1 : hasil belajar IPS dengan penggunakan model pembelajaran think pair share

A2 : hasil belajar IPS dengan pembelajaran reguler

$\mathrm{B} 1$ : kemandirian belajar tinggi

B2 : kemandirian belajar rendah

1) Berdasarkan hasil perhitungan diperoleh Fhitung $=4,912$ lalu dibandingkan dengan Ftabel dengan taraf signifikan 0,05, hasil Fhitung $(4,912)$ lebih besar dari Ftabel $(4,09)$. Dari hasil perhitungan tersebut maka hipotesis yang menyatakan ada pengaruh penggunaan model pembelajaran think pair share terhadap hasil belajar IPS terbukti kebenarannya. Artinya bahwa penggunaan model pembelajaran think pair share pada pembelajaran IPS terhadap hasil belajar siswa memiliki perbedaan yang signifikan.

1) Berdasarkan hasil ANAVA perhitungan diperoleh dengan nilai Fhitung $(4,580)$ lebih dari Ftabel $(4,09)$. Dari hasil perhitungan tersebut maka hipotesis yang menyatakan ada pengaruh kemandirian belajar terhadap hasil belajar IPS di SMP Negeri 2 Jember, terbukti kebenarannya. Dari kedua tingkat kemandirian menunjukkan siswa yang memiliki kemandirian tinggi memiliki hasil belajar yang lebih baik dibandingkan pada siswa yang memiliki kemandirian belajar kategori rendah.

2) Berdasarkan hasil perhitungan ANAVA dengan nilai Fhitung=4,232. Hasil perhitungan ini kemudian dikonsultasikan dengan tabel $\mathrm{F}$ dengan Dkpembilang 1 dan Dkpenyebut=39 dengan taraf signifikansi 0,05 diperoleh Ftabel $=4,09$. Karena Fhitung > Ftabel atau 4,232> 4,09, maka hipotesis yang menyatakan ada pengaruh interaksi penggunaan model pembelajaran think pair share dan kemandirian belajar siswa terhadap hasil belajar IPS terbukti kebenarannya. Artinya ada interaksi pengaruh kemandirian belajar, pembelajaran menggunakan think pair share atau pembelajaran reguler dengan hasil belajar IPS.

Pembelajaran IPS akan lebih bermakna bila dikaitkan dengan kehidupan nyata yang dialami siswa dan dapat mengembangkan keterampilan hidup termasuk di dalamnya keterampilan sosial. Pembelajaran IPS secara umum termasuk kelompok mata pelajaran ilmu pengetahuan sosial yaitu untuk mengenal, menyikapi, dan mengapresiasi ilmu pengetahuan dan tekhnologi serta menanamkan 
kebiasaan berpikir dan berprilaku ilmiah yang kritis dan mandiri. Penggunaan model pembelajaran think pair share memiliki langkah-langkah seperti thinking (berfikir), pairing (berpasangan), dan sharing (berbagi) yang dapat membuat siswa menemukan permasalahannya sendiri dan saling berbagi kepada yang lain, sehingga proses pembelajaran di kelas akan lebih efektif dan terjadi peningkatan hasil belajar siswa setelah proses pembelajaran tersebut. Hal ini dikarenakan siswa terlibat langsung dalam pembelajaran yang dapat memunculkan ide-ide dan cara berfikir siswa untuk menyalurkan kreatifitas siswa secara mandiri.

Kelebihan tersebut dapat terjadi apabila ada tanggung jawab individual anggota kelompok, artinya keberhasilan kelompok ditentukan oleh hasil belajar individual semua kelompok yang kinerjanya baik sehingga anggota kelompoknya tersebut dapat melihat bahwa kerja sama untuk saling membantu teman dalam satu kelompok sangat penting. Sedangkan kelemahan yang ada dapat diminimalisir dengan peran guru yang senantiasa meningkatkan motivasi siswa yang lemah agar dapat berperan aktif, meningkatkan tanggung jawab siswa untuk belajar bersama, dan membantu siswa yang mengalami kesulitan.

\section{PENUTUP}

\section{Kesimpulan}

Penggunaan model pembelajaran think pair share pada materi pokok pedosfer (tanah) pada prosesnya dapat memfasilitasi siswa untuk belajar lebih aktif (student centered), supaya tumbuh keberanian siswa untuk menuliskan ide/gagasannya, berani bertanya, memberi dan menerima pendapat teman, berbicara di depan kelas dan menanggapi suatu pendapat serta siswa dapat bekerjasama dan menghargai pendapat temannya. Pe Penggunaan model pembelajaran think pair share pada pembelajaran ini mengikuti langkah-langkah think pair share yang terdiri dari kegiatan pendahuluan, kegiatan inti (tahap think pair share) dan kegiatan penutup. Pembelajaran menggunakan media dan LKS yang dirancang disesuaikan dengan materi.

\section{Saran}

Berdasarkan pembahasan tentang penggunaan model pembelajaran think pair share dalam pembelajaran IPS maka peneliti memberikan saran sebagai berikut: (1) Bagi guru, hendaknya lebih cermat dalam memilih penggunaan variasi model pembelajaran yang dapat membantu siswa mengembangkan potensi yang dimilikinya serta guru diharapkan lebih kreatif dalam memancing siswa untuk berpikir kritis dan belajar secara mandiri sehingga dapat memicu siswa untuk lebih aktif dalam belajar. (2) Bagi siswa, diharapkan mampu mengikuti setiap tahap dalam pembelajaran dengan Think Pair Share yang dapat bermanfaat bagi peningkatan aktivitas siswa dan siswa hendaknya lebih kritis dan berani untuk mengungkapkan pendapat dan mampu berdiskusi pada teman atau guru, sehingga tercipta interaksi baik antar siswa maupun siswa dengan guru.

\section{DAFTAR PUSTAKA}

Eggen, Paul., Don Kauchak. 2012. Strategi dan Model Pembe-lajaran: Mangajarkan Konten Dan Keterampilan Berpikir. Jakarta: Indeks.

Komalasari, Kokom. 2011. Pembe-lajaran Konstektual: Konsep dan Aplikasi. Bandung: Refika Aditama.

Rusman. 2012. Model-model Pembelajaran: Mengembangkan Pro-fesionalisme Guru. Jakarta: Rajawali Pers.

Harjono, Ahmad.2012. Pengaruh strategi pembelajaran dan pemberian advance organizer serta prior knowledge terhadap hasil belajar fisika siswa kelas $\mathrm{X}$. Dalam http://jurnal- 
online.um.ac.id/data/artikel/artikel33C11FE977736E725B8CF2AEF143C572.pdf (Diunduh pada tanggal 20/10/2015 jam 13.00 WIB).

Ibrahim, M, dkk. 2000. Pembelajaran Kooperatif. Surabaya : University Press.

Lie, Anita. 2002. Cooperative Learning: Mempraktikkan Cooperative Learning di Ruang-ruang Kelas. Jakarta: PT Gramedia Widiasarana Indonesia.

S. Ichas Hamid Al Lamri, Tuti Istianti Ichas. 2006. Pengembangan Pendidikan Nilai Dalam Pembelajaran Pengetahuan Sosial di Sekolah Dasar. Depdiknas : Jakarta.

Slavin, Robert E. 2005. Cooperative Learning: Teori, Riset dan Praktik. Bandung: Nusa Media. 